\title{
Competence development needs for micro-enterprises entering servitisation
}

Erävala, K. T., Muhos, M., \& Ala-Rämi, K. (2021). Competence development needs for microenterprises entering servitisation. International Journal of Value Chain Management, 12(1), 86105. https://doi.org/10.1504/ijvcm.2021.112846

\begin{abstract}
Servitisation, as a means to drive growth, provides a great business opportunity for microenterprises (micros), offering the possibility of longer and more profitable customer relationships. However, such enterprises possess limited human resources and, thus, competences. Competence-related challenges must be understood in order to operate successfully in the field of servitisation. This study produces new knowledge about competence development needs. The study material consists of interviews conducted in ten Finnish subcontracting micros in the fields of forestry, agriculture, and mining. Using a multiple case approach allows for an extensive examination of the insufficiently studied phenomenon of interest — micros engaging in servitisation — utilising Tukker's (2004) product-service system. The results contribute both academically and practically by showing that micros face competence-related servitisation challenges in terms of entrepreneurship, change management, and financing. The study broadens Tukker's product-service categorisation to include product manufacturing industries that offer assembly services.
\end{abstract}

Keywords micro-enterprises, competences, servitisation, case study, human resource management 


\section{Introduction}

Servitisation has a great impact on customer value in terms of co-operation and individualisation (Carsten et al., 2017). Servitisation enhances the capabilities and processes of a company, creating mutual value for the company and its customers by re-shaping the firm's offerings from traditional products to product-service entities (Baines et al., 2009). A shift from selling a pure product to selling product-services naturally demands innovation in an organisations' capabilities and processes (Neely, 2007). With the business shift toward servitisation, in order to operate successfully with limited human resources and thus limited competences, it is crucial for micros to clarify the required competences. Therefore, the aim of this study is to produce new knowledge about the competence-related needs of microenterprises entering servitisation.

Servitisation was introduced in the 1980s to describe a new phenomenon that subsequently became known as the 'servitisation of manufacturing'. The term servitisation refers to a service that is additional to the core product offerings, such as maintenance, repair, and insurance of the products (Vandermerwe and Rada, 1988). Servitisation has increased in the 2000s, proving to be remarkably important for economic growth and employment in many countries (Johanssen and Olsen, 2010). The service sector accounts for over $70 \%$ of the European Union's (EU's) economic activity and employs nearly 70\% of the EU's workforce (Neely, 2007).

Micros employ one to nine people and have a turnover of $\leq € 2 \mathrm{~m}$ or a balance sheet total of $\leq$ $€ 2 \mathrm{~m}$ (European Commission, 2020). Micros account for over 93\% of European enterprises (Muller et al., 2019) and are considered to be a driver of the EU's economy. Despite their 
important role in the economy, there is a considerable gap in the literature regarding micros (Samujh, 2011; Kelliher and Reinl, 2009). However, it is widely acknowledged that micros experience resource scarcity, which forces them to operate under financial and expertise constraints (Kelliher and Reinl, 2009). Micros often employ a niche strategy that utilises incremental change and is prone to a short-term perspective (Kelliher and Reinl, 2009). Additionally, they are largely influenced by their owners and managers (Burns, 2010). Predominantly, a micro's culture is an extension of the owner's personality, as the owner plays a pivotal role in the organisation's focus and success (Kelliher and Reinl, 2009; Burns, 2010). When a micro-entrepreneur faces challenges, unexpected changes, or crises, he or she must usually solve them alone. Entering the field of servitisation may be an additional challenge to a micro's competences; therefore, it is crucial for micros to proactively evaluate their competence limitations and needs before entering the servitisation field. In addition, to acquire competitive business advantages with limited human resources, Barney, Wright, and Kechen (2001) stated that, '[although] much of the focus of RBV [resource-based view] research has been on larger firms ... smaller firms also face the need to acquire critical resources to create a sustainable competitive advantage' (p. 634). As stated, micro-enterprises have a huge economic influence, and on the other hand, servitisation offers great business opportunities. Accordingly, there is a need to clarify the competence-related development needs and possibilities of micros when entering servitisation.

The current paper used qualitative methods to examine competence-related development needs from various perspectives, focusing on the context of micros with limited resources. Although many academic studies have been conducted on this topic, research on servitisation seems to have concentrated on existing knowledge in the context of manufacturing industries (Kowalkowski at al., 2017). Micros generally act as subcontractors in various industries and 
thus offer a rich opportunity for research; hence, this study provides new practical and academic knowledge regarding the servitisation phenomenon.

The research was conducted in ten micro-enterprises operating in the manufacturing industry utilising Tukker's (2004) product-service system to evaluate their current servitisation business. However, the standard product-service value-delivering classification did not fit all the studied firms, so a new subcategory was added to Tukker's value-delivering categorisation of product-service systems (Tukker, 2004).

The study proceeds as follows. After introducing the purpose and reasoning behind the study, the paper presents the servitisation and competence literature relating to micros. The methodology is then described, followed by the findings and the discussion. The final section presents the research conclusions, implications, and suggestions for future research.

\section{Theoretical Background}

\section{Different competences and competencies}

A few competence-related studies have considered micros. Kelleher and Reinl (2009, p. 521) studied the competences and competitive advantages of micros, concluding that 'there is an assumption that knowledge must be used optimally within the micro-firm by developing the analytical and critical skills of individuals, groups and the entire organisation so as to sustain and grow these firms' competitive advantages'. Not all micros are the same size. Some entrepreneurs employ only themselves while others employ several people, so a study of competence must consider both individual and organisational competences. 
Before examining the previous literature, it is important to define competence/s and competency/ies. The terms are often used interchangeably and identified differently. However, at a high level there is a common view on how to define the terms. As informed in a literature snapshot in Table 1 below, competency/ies are connected to behaviour and the actions through which the (business) performance is achieved and focuses on how

Table 1: Competency/ies and competence/s

Please add Table 1 here

people do things (Taipale-Erävala, 2015), how to do/work (Sanghi, 2007), and how to become more successful (Teodorescu, 2006). Competence/s, in turn, are a skilled-based theme for measurable, specific, and objective milestones; that is, what people have to accomplish to achieve or exceed the goals (Teodorescu, 2006). Skill-based competence standards — what people can do (Sanghi, 2007) and what can be measured through accomplishments contributing to organisational success (Teodorescu and Binder, 2004) — are commonly used in educational training and for improving the skills and qualifications of the labor force (Taipale-Erävala, 2015). From the perspective of competence development, competency appears to be a job-specific theme, and a person is therefore unable to perform tasks or deal with situations beyond the prescribed outcomes (Brockmann et al., 2008). As a summary of the themes, descriptions, and definitions presented above, competency/ies in this study are defined following Klemp (1980) an 'an underlying characteristic of a person which results in effective and/or superior performance on the job' (p. 21). The study focuses on the competence development needs of micros entering servitisation. This is clearly a situation in which people may need to update their skills and attitudes, and thus new competences are 
required to consistently achieve or exceed the goals for their role, team, division, and organisation (Teodorescu, 2006). In the following, the term competency is used when discussing an as-is situation in a firm, while the term competence is related to either theoretical issues or future development needs.

A business starts up when an individual discovers an opportunity, turns an idea into a profitable innovation, and establishes an enterprise, thus becoming an entrepreneur (Shane, 2003). The act of discovering an idea, exploiting it, and executing it requires entrepreneurial competences. Entrepreneurial competences include scanning the future business environment, generating ideas, and identifying new business opportunities (Mitchelmore and Rowley, 2010). According to Chandler and Jansen (1992), entrepreneurial competences include entrepreneurial, managerial, and technical skills. In the case of micros, an entrepreneur is the individual who exploits and executes an idea, often acting as a manager and requiring managerial competences.

Managerial competences are crucial for enabling firms to develop other competences (Lado et al., 1992), including financial and human resource management, marketing, commercial, and leadership skills (Loué and Baronet, 2012). Financial abilities are stressed in manufacturing companies (Fernando et al., 2017). An entrepreneur orchestrates physical, human, and monetary resources and business performance by using managerial competences. When starting a business, an entrepreneur focuses first on physical and monetary resources and then on human resources, and the latter are usually limited in micros employing one to nine persons (European Commission, 2020). According to Teece et al. (1997), organisational competences are firm-specific assets formed by individuals and groups to facilitate the firm's performance. Organisational competences are similar to network competences (Ferrer et al., 
2009), which focus on inter-organisational networking and co-operation (Lambert and Cooper, 2000), and are based on individual competencies (Nurach et al., 2012).

Overall, individual competences create the basis for a firm's expertise; therefore, the effect of employees' skills and competences on a firm's performance is significant. Job competency (i.e. how an individual's skills apply to a job) is an underlying individual characteristic resulting in superior and effective performance at work (Boyatzis, 1982; Klemp, 1980). In order to achieve a competitive advantage, both employee and organisational competences are important (Hitt et al., 2005). The business environment changes constantly, and thus individuals and organisations must be willing to change. Change management competences allow firms to survive various business changes by developing skills and work methods and having a proactive attitude towards change (Taipale-Erävala, 2015).

Servitisation, as a modern trend, is a challenge for many companies, including micros. It is related to industrial manufacturing, and, in the face of technological change, small firms must allocate their limited resources efficiently (Confente et al., 2015). In servitisation, the supportive skill set includes flexibility, relationship building, service-centricity, technical adeptness, and resilience (Baines et al., 2012). All of these skills are strongly related to servitisation and thus to change management competences.

\section{Servitisation as a business opportunity}

Servitisation is an action whereby a 'firm offers bundles of customer-focused combinations of products, services, support, self-service and knowledge' (Vandermerwe and Rada, 1988) to enhance competitive advantages (Wise and Baumgarter, 1999; Neely, 2007; Baines et al., 
2009a). Over the years, product-service combinations have increasingly shifted from selling a product to customers toward leasing, hiring, pooling, and charging for availability or performance (Spring and Araujo, 2009). The boundary between products and services has thus been obscured (Ren and Gregory, 2007; Baines et al., 2009b). The empirical case study took into account this obscure boundary and broadly observed product-service combinations according to Tukker's categorisation of a product-service system (Tukker, 2004). Tukker's (2004) modified categorisation is introduced in Figure 1 below, including both the main and subcategories.

- please add Figure 1 here -

Figure 1. Product-service system (modified by Tuker, 2004)

Tukker's (2004) product-service system involves different ways of delivering value from a manufacturer to a customer. For a pure product, the value is mainly in the product's content, a buyer exchanges money for a product, and the product's ownership thus changes. Such an operation is product oriented. In a use-oriented operation, such as product leasing, renting, or pooling, the ownership of a product does not change: the manufacturer still owns the product but sells the usage of the product through a use-oriented business. The result-oriented action is in question when a product is in use, delivering value for a customer based on a pay-perservice unit or functional results. In a pure service business, the value is delivered mainly through the service.

Servitisation includes five challenge areas — organisational structure, business model, development process, customer management, and risk management - which could all be 
involved when entering deeper into servitisation (Zhang and Banerji, 2017). Product or service development (e.g. after-market services) have also become increasingly important for companies (Isoherranen and Majava, 2018) and thus represent a notable business opportunity. The aforementioned challenges demand different competences for entering and/or operating in a servitisation business.

\section{Research Methods, Data Collection, and Data Analysis}

The integration of products and services is a growing trend among companies of all sizes in today's globally competitive business environment (Mont, 2002), and this phenomenon is of equal importance for both product and service providers (Baines et al., 2009; Meier et al., 2010). The study thus aimed to clarify the competence development needs of microenterprises entering servitisation in the manufacturing industry and describe the everyday beliefs, opinions, and perspectives of micro-enterprise managers regarding the competencerelated challenges faced in this process. A case study research strategy was selected to achieve this goal. The unit of analysis of this study was micro-sized enterprises in the manufacturing industry.

The theoretical foundation of this study was the perspective on competence in the broad servitisation literature. Within the academic community, there is growing interest in developing a context-specific understanding of servitisation rather than seeking universal solutions; therefore, understanding phenomena in their contexts is becoming increasingly important. This study clarified the competence development of micro-enterprises entering servitisation within the manufacturing industry. Compared to single cases, theory-building based on the findings of multiple case studies typically yields more reliable (Baxter and Jack, 2008), robust, generalisable, and testable theories (Eisenhardt and Graebner, 2007). Multiple 
case studies provide a stronger basis for theory building (Yin 1994), and the propositions arising from them are more deeply grounded in diverse empirical evidence (Eisenhardt and Graebner, 2007). A case may be unique or special, operating according to a pattern (Stake, 1995). Micros and the competence-related challenges relating to servitisation are special cases because of their business novelty.

To study the competence-related development needs of micros, the following research questions were posed:

1. What specific competence-related needs do micros face when entering the field of servitisation?

2. What is the current state of servitisation in the studied micros?

3. What possibilities do micros have for entering/operating in servitisation?

The research employed a cross-sectional multiple-case study (Yin, 2009; Saunders et al., 2009). According to Yin (1989, p.23), 'a case study is an empirical inquiry that investigates a contemporary phenomenon within its real-life context ... when the boundaries between phenomenon and context are not clearly evident ... and in which multiple sources of evidence are used'. Further, Tellis (1997) stated that a case study research strategy produces detailed and holistic knowledge based on the analysis of multiple empirical, context-rich sources. It is a powerful research strategy that improves the knowledge of individual, group, organisational, and social phenomena (Yin, 2009). Case studies can produce rich descriptions of everyday life (Stake, 1995).

The current paper used qualitative methods to examine competence-related development 
needs from various perspectives, focusing on defining the phenomenon in the context of micros with limited resources. Generally, the competence literature has concentrated on large business units (Barney et al., 2001) and people who have specialised sets of competences that enable them to perform specific tasks within a company. However, in a micro-sized firm, it is not possible to concentrate on specialised skills, as everyone must perform several tasks (Taipale-Erävala, 2015); thus, the current competence literature cannot be applied to micros. This study contributes to management development and training in the context of microbusiness entrepreneurship by narrowing the gap in qualitative case study research (Devins $e t$ $a l ., 2005)$. Qualitative research and face-to-face interviews are informative and were chosen because they facilitate a deep understanding of a phenomenon. Although many academic studies have been conducted on this topic, research on servitisation has largely concentrated on existing knowledge in the context of manufacturing industries (Kowalkowski et al., 2017). Micros generally act as subcontractors in various industries and thus offer a rich opportunity for research; hence, this the results of this study provide new knowledge regarding the servitisation phenomenon. The research process of this study is presented in the Figure 2.

- please add Figure 2 here -

Figure 2. The research process of this study

The data collection protocol involved individual, focused interviews. In a focused interview, the aim is to collect data by interviewing a person or people for a short period of time (Yin, 2009). The data were collected from ten Finnish micros, using semi-structured interviews to ensure that rich and focused information was collected (Merriam, 2009). A qualitative 
approach was selected to obtain a better understanding of the context within which decisions were made and actions were performed (Myers, 2009). The representatives of the micros were interviewed by trained researchers who had expertise in servitisation and knowledge of competence theories. The firms were selected according to their industry, size, and location. The case companies represented Finnish micros functioning in the industry. The interviews were conducted in a manufacturing industry-related project carried out between 2017 and 2019. Table 2 summarises the studied micros and the interviews.

Table 2: Descriptions of the interviewees and their interviews

- please add Table 2 here -

Before the interviews, all the interviewees received a semi-structured questionnaire to familiarise themselves with the topics. During the interviews, the order of the topics varied. The interviewer allowed each interviewee to discuss the topics freely since a relaxed atmosphere allows people to talk openly about their opinions, beliefs, and experiences. The questions were clarified and repeated if necessary in order to ensure the interviewees' comprehension. The central themes covered by the interviews were: (1) customers, (2) offerings, (3) value proposition, (4) sales structure, and (5) present and future challenges. Before each interview, the researcher explored the publicly available secondary data pertaining to each micro.

A modified grounded theory-based process (Easterby-Smith et al., 1991) was used to conceptualise the framework through the classification of data relating to the research questions (Merton and Kendal, 1957). The interviews were first coded, based on the research 
questions, and then the main coded items were grouped and categorised according to their similarities.

The findings are presented separately as they relate to the research questions, RQ1, RQ2, and RQ3. First, analysis of the data relating to the first research question (RQ1) revealed the following competence needs: entrepreneurial and managerial, individual entrepreneurial, individual employee, financial, and change-management competences. Table 2 presents the competence-related needs classified in the first phase of the coding, with examples taken directly from the interviews.

Second, the investigation of the data relating to the second research question (RQ2) illustrated the current state of servitisation in the studied micros based on Tukker's classification of a product-service system. Third, the analysis of the data relating to the third research question (RQ3) revealed that limited human resources are a major challenge for micros entering the field of servitisation.

\section{Findings}

\section{Specific competence-related needs of micros entering the field of servitisation}

The competence-related needs are categorised in Table 3 below and divided into entrepreneurial and managerial competences, the individual competences of entrepreneurs and employees, financial competences, and change-management competences.

Table 3: Competence-related needs 
- please add Table 3 here -

Entrepreneurial and managerial competences were treated together because, in a micro, the entrepreneur also acts as the manager. Entrepreneurial competences included searching for new business opportunities by scanning the business environment and developing new business ideas. It is possible to exploit servitisation by searching for new business opportunities and, for example, increasing digitisation or increasing the number of services rather than simply producing products. Passivity was a competence-related challenge in searching for new business, as noted in case 3: 'We need to search for longer customer relationships and partnerships, but we have not achieved them, and this is our challenge in the field of marketing'. Another challenge was clarifying disparate business plans, as noted in case 4: 'The [business plan] needs to be cleared up, because our resources will not last long'. Selling through a lazy retailer posed problems for sales and marketing. As one interviewee remarked, 'If we sold ourselves, we would sell twice as much our lazy retailer does' (case 10).

Individual competences were examined from the points of view of both entrepreneurs and employees, as micros with only a few employees may become competent and successful only by networking or acquiring other competences. A lack of language proficiency was found to be a challenge, as noted in case 1: 'My language proficiency is limited. I had to choose either technology or language. I chose technology'. A need for networking was reported in case 7: 'I could find a partner and get together a packet, but it has failed to happen'. Entrepreneurs' bankruptcies were regarded as hampering existing and new business, as in case 9: 'As a key 
challenge and a burden, I experienced bankruptcies. Those (bankruptcies) did not necessarily hamper company directors, but did hamper some people at a site' (case 9).

Micros faced challenges in terms of the unavailability of professional and permanent personnel; hence, the micros had to train employees in order to obtain the skills they needed, as noted in cases 1 and 4: 'I have trained about ten guys but, when they are skilled, they take their papers [job applications] elsewhere'; 'We have to recruit, but it is terribly difficult to find employees' (case 1); 'This is a special field; it takes time for a person to learn' (case 4).

Financial competences are important in enabling micros to secure financial capital and ensure low turnover. Servitisation is a novel issue, and observations regarding its financial effect on business operations are scarce. In a start-up, 'it [servitisation] may be a goal in the future, but it demands resources from the company and the organisation. We do not possess such resources at the moment' (case 6). In the interviews, the issue of insurance came up unexpectedly. When asked about the financial considerations when entering the field of servitisation, one interviewee stated, 'Goodness! Insurance is the greatest nuisance!' (case 7).

Change is difficult to implement because entrepreneurs may cling to past security, as seen in case 5: 'It is kind of difficult to experiment away from here, because the work there remains undone and the work here remains undone'. In addition, customers or industries may avoid novel business solutions and want to continue as usual, which interferes with servitisation, as seen in case 2: 'The culture [in mining] is such that people want to do things that they have done before, in the same way'. At times, customers' do-it-yourself attitudes prevented new sales, as noted in case 1: 'You [the customer] can get the best profit from using new skills'. 


\section{The current state of servitisation in the studied micros}

The phases of the micros' servitisation were classified according to Tukker's (2004) categorisation of a product-service system, using main categories and subcategories (see Table 4 below). The main categories were Pure Product, Product Oriented (A), Use Oriented (B), Result Oriented (C), and Pure Service. Each main category had various subcategories (A1, A2, B3, B4, B5, C6, C7, and C8), and thus the micros' servitisation phases were informed by eight types of product--service systems. The Pure Product phase was combined with the Product Oriented phrase (category A), and the Pure Service phase was combined with the Result Oriented phase (category C).

Table 4: The current state of servitisation in the studied micros

- please add Table 4 here -

The results indicated that two of the micros performed pure product business, employing personal product user information, and three micros conducted pure service business. The remaining five micros were categorised as product-oriented businesses, and two of them fell into subcategory A2: Advice and Consultancy. One of the additional micros did not match category A, and thus it was recommended that Tukker's categorisation (2004) be supplemented with a new subcategory: A3. This new category refers to manufacturing companies that assemble components for larger equipment. The remaining two micros operated as result-oriented businesses delivering functional results for their customers.

\section{The opportunities for micro-enterprises to enter/operate in servitisation}


The study focused on the competence development needs of micros entering into or considering servitisation. RQ3 concentrated on clarifying the opportunities for micros to enter/operate in servitisation. The study approached the question by considering micros' limited resources.

Servitisation requires planning. When a micro considers providing more services, it may lack time and face challenges in increasing its business operations, changing employees' individual attitudes, and recruiting skilled and motivated personnel. These challenges are presented in Table 5.

Table 5 Limitations of human resources for micros entering the field of servitisation - please add Table 5 here -

A lack of time is a common challenge for small firms, as confirmed by this study. The research question targeted the influences of limited human resources, which were manifested in inadequate marketing efforts (case 3) and a need for familiarisation with servitisation (case 1). Based on the research, servitisation seemed to be connected to international business, which naturally depends on the industry of the micro.

Overall, micros lacked resources for servitisation (case 6), which may indicate limited physical or financial resources. In addition, servitisation seemed to be a major issue for micros (case 8). Servitisation involves the provision of certain additional services, such as 
maintaining devices; thus, employees often had to work outside the micro's premises. The study revealed that employees were unwilling to work far away from their home locations (cases 5 and 8), which made servitisation challenging. In manufacturing industries, servitisation was largely operated by subcontractors serving large companies, and SME bankruptcies were experienced as preventing access to a site (case 9). A retailer's minimal marketing actions could also be an obstacle to engaging in servitisation (case 10).

In addition, recruiting challenges hindered micros from entering the field of servitisation. Although micros wanted to offer advanced services to their customers, the unavailability of competent personnel (cases 1 and 5) prevented this. Moreover, the attraction of candidates varied by industry, as young people were generally uninterested in working in some industries, such as mining (case 5).

\section{Discussion}

The findings indicated that Tukker's product-service value-delivering categorisation was unsuitable for various fields of industry. When the micros' businesses were categorised according to Tukker's (2004) product-service system, nine of the ten micros' businesses were either pure product/product-oriented or pure service/result-oriented businesses. One micro's business, involving traditional subcontracting with additional assembly services, did not correspond to Tukker's (2004) product-service system; thus, the study recommends extending the product-service system with a new sub-category (A3). The novel sub-category A3 would be more appropriate to the current product-service system in manufacturing industries.

Entering the field of servitisation requires business operations to change; thus, competences 
also need to change through adopting a proactive attitude toward change, the ability to tolerate uncertainty, and the willingness to develop new skills and work methods (TaipaleErävala, 2015). The micros acknowledged the industrial change but did not mention human resource allocation as a competitive issue (Confente et al., 2015). By networking with other micros, the enterprises could benefit from a wider range resources and collaborate to maximise competences in response to various operational factors (Ferrer et al., 2009).

A business starts up when an individual discovers an opportunity, turns an idea into a profitable innovation, and establishes an enterprise, thus becoming an entrepreneur (Shane, 2003). Entrepreneurial competences focus on scanning the future business environment, generating ideas, and identifying new business opportunities (Mitchelmore and Rowley, 2010). This study indicated that the micros desired long-term customer relationships in order to ensure business continuity, but they did not view servitisation as a solution. In addition, the micros possessed unclear business plans due to their limited resources, which could be solved by the development of proper entrepreneurial and managerial competences (Chandler and Jansen, 1992).

In terms of managerial competences (Loué and Baronet, 2012), marketing and financial issues were challenging. Marketing actions focused on acquiring more customers and orders while neglecting financial issues, which could deeply harm small businesses. While a firm's lazy retailer could be an obstacle to increasing business, a shift from using a retailer to selfmarketing and selling requires the courage to execute the change and the employment of internal sales and marketing personnel, which naturally involves additional costs. Overall, servitisation seems to increase the need for financial ability and economic knowledge in micros. Advanced services may produce high revenues for micros, but they may also result in 
higher costs due to increased investment. According to this study, the micros perceived variable costs, especially insurance costs, to be the biggest challenge, although fixed costs might actually cause bigger problems.

Individual competences refer to all human features — abilities, attitudes, capabilities, skills, and experiences — that can affect job performance (Boyatzis, 1982; Klemp, 1980). Both employee and organisational competences are important (Hitt et al., 2005). This study indicated a lack of individual competences (e.g. lack of language proficiency and the inability to achieve a desired goal) and frustration surrounding the trend of training competent employees only to lose them. The unavailability of skilled and competent personnel is a challenge that relates to both the individual competences of employees and to entrepreneurial and managerial competences, as entrepreneurs are in charge of recruiting employees.

Discovering the reasons for employee turnover would allow entrepreneurs to enhance their managerial and entrepreneurial competences. Perhaps the most surprising finding was that the bankruptcies of SMEs could prevent access to sites. Maintaining or running down a business in a controlled way involves a high level of entrepreneurial skill, which should be viewed as a developmental skill rather than as a preventive one.

Regarding opportunities to enter/operate in servitisation, it was found that limited human resources caused a lack of time. It takes time for entrepreneurs and employees to acquire knowledge and become familiar with servitisation, but small firms can lower this threshold by networking. Sharing resources and building trust with partners in a network broadens human resources and enables efficient, flexible, high-quality, and time-based operations (Ferrer et al., 2009). The studied micros had not considered network co-operation, but it could enable them to broaden their human and other resources in the future. 
The study revealed some challenges to business growth, such as overall limited resources or an entrepreneur's unwillingness or inability to see his or her business as a growing one. A perspective that 'servitisation is too big for a small firm ... small remains small' reflected, to some degree, ignorance about the possibilities of servitisation for companies of all sizes. Surprisingly, a controlled bankruptcy was experienced as an obstacle, although the ability to control bankruptcy was considered a significant skill. In addition, the quality of personnel prevented micros from entering the field of servitisation. Employees' individual attitudes and conditions influenced new business outputs. The unwillingness to work outside the firm's premises and the pursuit of ambition indicated the employees' personal valuation of work circumstances and institutional and social appreciation, all of which a micro may find difficult to change.

As a result, this study suggests broadening Tukker's product-service value delivering categorisation to include product manufacturing industries that offer assembly services. Overall, from the perspective of competences, micros must seriously consider strengthening their managerial, individual, change management, and financial competences in order to enter the business of servitisation.

\section{Conclusion}

The study, conducted in ten micro-enterprises operating in the manufacturing industry, focused on examining the competences that micros need to enter the field of servitisation. Empirical and qualitative methods were used to specifically target the competence-related needs of micros, especially those caused by limited human resources. Additionally, the research studied the current state of servitisation and the micros' opportunities to enter 
servitisation.

The findings highlighted that servitisation is quite novel and unfamiliar to micros. Most of the interviewed firms served large companies in the forestry and mining industries, where servitisation has been used for years. Although some micros operated in industries in which servitisation was used, they did not necessarily recognise it as an important business trend; rather, they saw it through the lens of the status quo. However, the micros will eventually face a need for servitisation. Thus, the sooner the enterprises familiarise themselves with the basic issues of implementing servitisation, the sooner they will benefit from the business obtained by providing advanced services.

Overall, the study provided novel insights into the role and importance of micro-enterprises' competence development needs when entering the servitisation business. These insights can be useful for both researchers and practical actors in the field of servitisation.

In conclusion, this study determined the competence-related needs of micro-enterprises, including a lack of time and the unavailability of competent personnel, both of which are connected to limited human resources. These needs could be eased through networking and co-operation with other small enterprises. This study also identified the importance of entrepreneurial competences, focusing on discovering new business opportunities and exploiting possibilities for servitisation. In addition, it was found that micros need financial competences to increase their awareness of investments and costs, which may fall on a supplier rather than a subcontractor. Finally, this study found that servitisation changes the business environment. Overall, through the use of change management competences, it becomes easier for micros to enter and operate in the field of servitisation by exploiting its 
possibilities (e.g. by broadening the business from subcontracting to a subcontractorassembler).

The suggestions of the paper can be utilised in realising the potential of new business for micros in servitisation and acquiring the competences required for this new business opportunity. Additionally, the results of the study offer valuable knowledge for the business advisory services utilised in micro-enterprise business. Regarding theoretical implications, the study narrows the literature gap and contributes new knowledge regarding microenterprises; it also contributes to competence research (Samujh, 2011; Kelliher and Reinl, 2009; Baines et al., 2012). Additionally, the study innovatively contributes to servitisation research by proposing a novel sub-category of Tukker's product-service system (Tucker, 2004). In the manufacturing industry, large companies, in addition to contracting out device manufacturing, need to consider increasing their subcontracting of assembly services; thus, the subcontracting micros would be encouraged to enter into servitisation based on their clients' preferences. Ideally, micros and small firms will realise the huge opportunity for new business by operating as both subcontractors and assemblers.

This study was limited to examining the competence-related needs of micro-enterprises entering the field of servitisation in manufacturing industries. In order to gain a broader understanding of micros' competence-related challenges, there is a need for further research in other industries. Additionally, the data were collected in a Finnish context. To study attitudinal and other competence-related challenges, observing the phenomena in other contexts is recommended (different countries, regions, cultures, business ecosystems, etc.). This could open up new avenues of research; for example, regarding the cultural factors influencing the willingness to work outside the home business ecosystem or personal 
valuations of work circumstances. Moreover, in addition to studying the phenomenon in the context of micro-sized enterprises, as this study did, there is a need to investigate the competence-related challenges of small and medium-sized as well as large enterprises entering the field of servitisation. 


\section{References}

Barney, J., Wright, M. and Ketchen, D.J. (2001) 'The resource-based view of the firm: ten years after 1991', Journal of Management, Vol. 27, pp. 625-641.

Baines, T.S., Lightfoot, H.W., Benedettini, O. and Kay, J.M. (2009a) 'The servitisation of manufacturing: a review of literature and reflection on future challenges', Journal of Manufacturing Technology Management, Vol. 20 No. 5, pp. 547-567.

Baines, T.S., Lightfoot, H., Peppard, J., Johnson, M., Tiwari, A., Shehab, E. and Swink, M. (2009b) 'Towards an operation strategy for product-service servitisation', International Journal of Operations \& Production Management, Vol. 29 No. 5, pp. 494-519.

Baines, T. and Lightfoot, H. (2014) 'Servitisation of the manufacturing firm', International Journal of Operations and Production Management, Vol. 32 No. 1, pp. 2-35.

Baxter, P. and Jack, S. (2008) 'Qualitative case study methodology: study design and implementation for novice researchers', The Qualitative Report, Vol. 13 No. 4, pp. 544559.

Biemans, H., Nieuwenhuis, L., Poell, R., Mulder, M., and Wesselink, R. (2004)

'Competence-based VET in the Netherlands: background and pitfalls', Journal of Vocational Education \& Training, Vol. 56 No. 4, pp. 523-538.

Boyatzis, R.E. (1982) The Competence Manager: A Model for Effective Performance, John Wiley \& Sons, New York.

Brockmann, M., Clarke, L. and Winch, C. (2008) 'Knowledge, skills, competence: European divergences in vocational education and training (VET) — the English, German and Dutch cases', Oxford Review of Education, Vol. 34 No. 5, pp. 547-567.

Burns, P. (2010) Entrepreneurship and Small Business: Start-up, Growth and Maturity, 3rd ed., Palgrave Macmillan, Basingstoke. 
Carsten, C., Müller-Stewens, G. and Zimmermann, A. (2017) Radical Business Model Transformation: Gaining the Competitive Edge in a Disruptive World, 1st ed., Kogan Page Publishers, London.

Chandler, G.N. and Jansen, E. (1992) 'The founder's self-assessed competence and venture performance', Journal of Business Venturing, Vol. 7 No. 3, pp. 223-236.

Confente, I., Buratti, A. and Russo, I. (2015) 'The role of servitization for small firms: drivers versus barriers', International Journal of Entrepreneurship and Small Business, Vol. 26 No. 3, pp. 312-331.

Devins, D., Gold, J., Johnson, S. and Holden, R. (2005) 'Conceptual model of management learning in micro businesses - implications for research and policy', Education \& Training, Vol. 47 Nos. 8/9, pp. 540-551.

Easterby-Smith, M., Thorpe, R. and Lowe, A. (1991) Management Research, SAGE Publications Ltd, London.

Eisenhardt, K.M. and Graebner, M.E. (2007) 'Theory building from cases: opportunities and challenges', Academy of Management Journal, Vol. 50 No. 1, pp. 25-32.

European Commission, (2020), What is an SME? [online] https://ec.europa.eu/growth/smes/business-friendly-environment/sme-definition_en.

Fernando, Y., Sharon, S., Wahyuni, I. and Tundys, B. (2017) 'The effects of reverse logistics on cost control abilities: an insight into manufacturing companies in Malaysia', International Journal of Value Chain Management', Vol. 8 No. 4, pp. 285-306.

Ferrer, M., Santa R., Soosay, C. and Hyland, P. (2009) The critical competences needed for innovative organisational inter-firm and intra-firm integration [online] http://eprints.qut.edu.au/27156/1/CINet_09_-_Ferrer.pdf.

Hitt, M.A., Ireland, R.D. and Hoskisson, R.E. (2005) Strategic management: competitiveness and globalization, 6th ed., KY7 South-Western, Versailles. 
Isoherranen, V. and Majava, J. (2018) 'Customer care excellence in new product development process: a case study', International Journal of Value Chain Management, Vol. 9 No. 1, pp. 26-37.

Kelliher, F. and Reinl, L. (2009) 'A resource-based view of micro-firm management practice', Journal of Small Business and Enterprise Development, Vol. 16 No. 3, pp. $521-532$.

Klemp, G.O. (1980) The Assessment of Occupational Competence, Report to the National Institute of Education, Washington, DC:

Kowalkowski, C., Gebauer, H. and Oliva, R. (2017) 'Service growth in product firms: past, present, and future', Industrial Marketing Management, Vol. 60, pp. 82-88.

Lado, A.A., Boyd, N.G. and Wright, P. (1992) 'A competency-based model of sustainable competitive advantage', Journal of Management, Vol. 18 No. 1, pp. 77-91.

Lambert D. and Cooper, M. (2000) 'Issues in supply chain management', International Marketing Management, Vol. 29 No. 1, pp. 65-83.

Loue, C. and Baronet, J. (2012), 'Toward a new entrepreneurial skills and competencies framework: a qualitative and quantitative study', International Journal of Entrepreneurship and Small Business, Vol. 17 No. 4, pp. 455-477.

Meier, H., Roy, R. and Seliger, G. (2010) 'Industrial product-service systems - IPS ${ }^{2}$, $C I R P$ Annals - Manufacturing Technology, Vol. 59, pp. 607-627.

Merriam, S. (2009), Qualitative Research, A Guide to Design and Implementation, JosseyBass, John Wiley \& Sons, Inc., San Francisco.

Merton, R.K. and Kendal, P.C. (1957) The Student Physician, Harvard University Press, Cambridge. 
Mitchelmore, S. and Rowley, J. (2010) 'Entrepreneurial competencies: a literature review and development agenda', International Journal of Entrepreneurial Behaviour \& Research, Vol. 16 No. 2, pp. 92-111.

Muller, P., Robin, N., Jessie, W., Schoder, J. et al. (2019) Annual Report on European SMEs 2018/2019-Research \& Development and Innovation, Contract number:

EASME/COSME/2017/031, European Union.

Myers, M. (2009) Qualitative Research in Business and Management, Sage Publications, London.

Nurach, P., Thawesaengskulthai D. and Chandrachai, A. (2012) 'Developing an organization competencies framework for SME(s) in Thailand', Chinese Business Review, Vol. 11 No. 2, pp. 233-241.

Neely, A. (2007) 'The servitisation of manufacturing: an analysis of global trends' in The $14^{\text {th }}$ European Operations Management Conference Proceedings, Ankara.

Ren, G. and Gregory, M. (2007) Servitisation in Manufacturing Companies: A Conceptualization, Critical Review and Research Agenda, University of Cambridge, San Francisco.

Samujh, H.R. (2011) 'Micro-businesses need support: survival precedes sustainability, corporate governance', The International Journal of Business in Society, Vol, 11 No. 1, pp. 15-28.

Saunders, M., Lewis, P. and Thornhill, A. (2012) Research Methods for Business Students, 6th ed., Pearson, Essex, U.K.

Saunders, M., Lewis, P. and Thornhill, A. (2007) 'Research Methods for Business Students', in Financial Times, Prentice Hall, London.

Spencer. L.M. Jr and Spencer, S.M. (1993) Competence at Work, John Wiley \& Sons, New York. 
Sanghi, S. (2007) The Handbook of Competency Mapping: Understanding, Designing and Implementing Competency Models in Organizations, Response Books, New Delhi.

Shane, S. (2003) A General Theory of Entrepreneurship. The Individual-Opportunity Nexus, Edward Elgar, Cheltenham.

Spring, M. and Araujo, L. (2009) 'Service, services and products: rethinking operations strategy', International Journal of Operations \& Production Management, Vol. 29 No. 5, pp. 444-467.

Stake, R. (1995) The Art of Case Study Research, SAGE Publications Ltd, California.

Taipale-Erävala, K. (2015) Survival Competencies in SMEs in Changing Business Environments. PhD thesis. Åbo Akademi University. http://urn.fi/URN:ISBN:978-952$12-3296-1$

Teece D., Pisano, G. and Shuen, A. (1997) 'Dynamic capabilities and strategic management', Strategic Management Journal, Vol. 18 No. 7, pp. 509-533.

Tellis, W. (1997) 'Introduction to case studies', The Qualitative Report, Vol. 3 No. 2. [online] https://nsuworks.nova.edu/tqr/vol3/iss2/4/.

Teodorescu, T. and Binder. K. (2004) 'Getting to the bottom line: Competence is what matters', Performance Improvement, Vol. 43 No. 8, pp. 8-12.

Teodorescu, T. (2006) 'Competence versus competency What is the Difference?', Performance Improvement, Vol. 45 No. 10, Nov/Dec 2006, pp. 27-30.

Tukker, A. (2004) 'Eight types of product-service system: eight ways to sustainability? Experiences from Suspronet', Business Strategy and the Environment, Vol. 13, pp. 246260.

Vandermerwe, S. and Rada, J. (1988) 'Servitisation of business: adding value by adding services', European Management Journal, Vol. 6 No. 4, pp. 314-324. 
Wise, R. and Baumgarter, P. (1999) 'Go downstream: the profit imperative in manufacturing', Harvard Business Review, Vol. 77 No. 5, pp. 133-141.

Yin, R. (2009) Case Study Research, Design and Methods, Sage Publications Inc., California.

\section{TABLES}

Table 1: Competency/ies and competence/s

\begin{tabular}{|c|c|c|}
\hline Author & Competency/ies & Competence/s \\
\hline $\begin{array}{l}\text { Teodorescu and } \\
\text { Binder (2004) }\end{array}$ & $\begin{array}{l}\text { Competencies are behaviours } \\
\text { or (more often) abstract } \\
\text { categories of behaviour. }\end{array}$ & $\begin{array}{l}\text { Competence is measured by the } \\
\text { accomplishment of results that contribute } \\
\text { organizational success. }\end{array}$ \\
\hline Teodorescu (2006) & $\begin{array}{l}\text {... the definition } \\
\text { of skills, knowledge, } \\
\text { attributes, and behaviors that } \\
\text { successful people have. The } \\
\text { skills, knowledge, attributes, } \\
\text { and behaviors of successful } \\
\text { people may motivate other } \\
\text { people to acquire such traits } \\
\text { to become more successful. }\end{array}$ & $\begin{array}{l}\text {... the definition } \\
\text { of measurable, specific, and objective } \\
\text { milestones } \\
\text { describing what people must } \\
\text { accomplish to consistently } \\
\text { achieve or exceed the goals for their } \\
\text { role, team, division, and organisation. }\end{array}$ \\
\hline Sanghi (2007) & $\begin{array}{l}\text { behaviour-based, manner of } \\
\text { behaviour, how the standard } \\
\text { is achieved } \\
\text { how to do/work it }\end{array}$ & $\begin{array}{l}\text { skill-based, standard of achievement, } \\
\text { what is measured } \\
\text { what a person can do }\end{array}$ \\
\hline
\end{tabular}




\begin{tabular}{|c|c|c|}
\hline $\begin{array}{l}\text { Brockmann et al. } \\
\text { (2008) }\end{array}$ & $\begin{array}{l}\text {... as people are required to } \\
\text { perform based on narrowly } \\
\text { prescribed competencies, } \\
\text { they do not have the } \\
\text { knowledge, skills or, indeed, } \\
\text { the motivation to perform } \\
\text { tasks or deal with situations } \\
\text { beyond the prescribed } \\
\text { outcomes. }\end{array}$ & $\begin{array}{l}\ldots \text { as the ability to deal with complex } \\
\text { work situations, drawing on multiple } \\
\text { resources that the employee brings to } \\
\text { the workplace. ... a holistic notion, } \\
\text { relating to the whole person and } \\
\text { including different dimensions (e.g. } \\
\text { occupational, personal, and inter- } \\
\text { personal). }\end{array}$ \\
\hline $\begin{array}{l}\text { Taipale-Erävala } \\
\text { (2015) }\end{array}$ & $\begin{array}{l}\text { behaviour-based; the actions } \\
\text { through which the } \\
\text { performance } \\
\text { is achieved, focusing on how } \\
\text { people do things. }\end{array}$ & $\begin{array}{l}\text { skill-based standard; what people can } \\
\text { do, commonly used in educational } \\
\text { training and human resource } \\
\text { development to improve the skills and } \\
\text { qualifications of the labour force. }\end{array}$ \\
\hline
\end{tabular}

Table 2: Descriptions of the interviewees and their interviews

\begin{tabular}{llllll}
\hline Case & Industry in which & Number & Interviewee(s) & Length of & Turnover \\
& the firm operated & of & & interview & (Euros) \\
& & & & of micros \\
& & & & & \\
\hline $1 . \quad$ Fomployees & & & \\
& & $2-3$ & Managing & $1 \mathrm{~h}$ & \\
& & & director & & \\
\hline
\end{tabular}




\begin{tabular}{|c|c|c|c|c|c|}
\hline 2. & $\begin{array}{l}\text { Mining and delivering } \\
\text { comprehensive ICT } \\
\text { services and solutions }\end{array}$ & 5 & $\begin{array}{l}\text { Managing } \\
\text { director and } \\
\text { marketing } \\
\text { manager }\end{array}$ & $1 \mathrm{~h} 18 \mathrm{~min}$ & 243000 \\
\hline 3. & $\begin{array}{l}\text { Machining, } \\
\text { subcontracting }\end{array}$ & 5 & $\begin{array}{l}\text { Managing } \\
\text { director and } \\
\text { chief financial } \\
\text { officer }\end{array}$ & $1 \mathrm{~h}$ & 450000 \\
\hline 4. & $\begin{array}{l}\text { Supplying electrical } \\
\text { devices and } \\
\text { equipment for mining } \\
\text { and community } \\
\text { infrastructure building }\end{array}$ & 2 & $\begin{array}{l}\text { Managing } \\
\text { director }\end{array}$ & $1 \mathrm{~h} 16 \mathrm{~min}$ & 700000 \\
\hline 5. & $\begin{array}{l}\text { Maintenance services } \\
\text { in the mining industry }\end{array}$ & 8 & $\begin{array}{l}\text { Managing } \\
\text { director }\end{array}$ & $59 \mathrm{~min}$ & 900000 \\
\hline 6. & $\begin{array}{l}\text { Manufacturing high- } \\
\text { speed electronics for } \\
\text { the mining and steel } \\
\text { industries, } \\
\text { pharmacies, and bio- } \\
\text { pharmacies }\end{array}$ & 6 & $\begin{array}{l}\text { Managing } \\
\text { director and } \\
\text { marketing } \\
\text { manager }\end{array}$ & $1 \mathrm{~h} 11 \mathrm{~min}$ & 233000 \\
\hline 7. & $\begin{array}{l}\text { Diving and } \\
\text { underwater work for } \\
\text { industries, }\end{array}$ & 1 & $\begin{array}{l}\text { Managing } \\
\text { director }\end{array}$ & $1 \mathrm{~h} 2 \mathrm{~min}$ & 150000 \\
\hline
\end{tabular}




\begin{tabular}{|c|c|c|c|c|c|}
\hline & $\begin{array}{l}\text { municipalities, and } \\
\text { ports }\end{array}$ & & & & \\
\hline 8. & $\begin{array}{l}\text { Installing equipment } \\
\text { for the forestry, } \\
\text { mining, energy, and } \\
\text { steel industries, } \\
\text { including } \\
\text { maintenance and } \\
\text { welding }\end{array}$ & $\begin{array}{l}4, \\
\text { temporary } \\
\text { staff when } \\
\text { needed }\end{array}$ & $\begin{array}{l}\text { Managing } \\
\text { director }\end{array}$ & $1 \mathrm{~h} 8 \mathrm{~min}$ & 480000 \\
\hline 9. & $\begin{array}{l}\text { Installation, } \\
\text { supervisory, and } \\
\text { project management } \\
\text { services for the } \\
\text { supervision of work, } \\
\text { planning of } \\
\text { installations, and } \\
\text { calculation of } \\
\text { contracts }\end{array}$ & 3 & $\begin{array}{l}\text { Managing } \\
\text { director }\end{array}$ & $1 \mathrm{~h} 38 \mathrm{~min}$ & 150000 \\
\hline 10. & $\begin{array}{l}\text { Agricultural devices, } \\
\text { subcontracting }\end{array}$ & 6 & $\begin{array}{l}\text { Managing } \\
\text { director }\end{array}$ & $1 \mathrm{~h} 22 \mathrm{~min}$ & 500000 \\
\hline
\end{tabular}

Table 3: Competence-related needs 


\begin{tabular}{|c|c|c|}
\hline & Examples & Quotations \\
\hline Entrepreneurial & A lack of entrepreneurial & 'We need longer customer \\
\hline and managerial & competences (case 3 ) & relationships and partnerships, but \\
\hline \multirow[t]{9}{*}{ competence } & Not actively looking for new & we have not achieved them, and \\
\hline & business opportunities (case 3 ) & this is our challenge in the field of \\
\hline & A lack of managerial & marketing' (case 3) \\
\hline & competence in clarifying & 'The [business plan] needs to be \\
\hline & business plans (case 4 ) & cleared up because our resources \\
\hline & The courage to market the & will not last long' (case 4) \\
\hline & firm's own products instead of & 'If we sold ourselves, we would \\
\hline & through a retailer (case 10 ) & sell twice as much our lazy retailer \\
\hline & & does' (case 10) \\
\hline Individual & A lack of language proficiency, & 'My language proficiency is \\
\hline competence & which is an obstacle to & limited. I had to choose either \\
\hline \multirow[t]{11}{*}{ (entrepreneur) } & increasing international trade & technology or languages. I chose \\
\hline & (case 1$)$ & technology' (case 1) \\
\hline & In a network, a single & 'I could find a partner and get \\
\hline & entrepreneur is able to conduct & together a packet, but it has failed \\
\hline & more work; however, in a & to happen' (case 7) \\
\hline & network, not everyone & 'As a key challenge and a burden, \\
\hline & possesses network competences & I experienced bankruptcies. Those \\
\hline & (case 7$)$ & (bankruptcies) did not necessarily \\
\hline & Bankruptcy prevented the first & hamper the company's' directors, \\
\hline & entry into partnership with a & but did hamper some people at a \\
\hline & large company (case 9) & site' (case 9) \\
\hline
\end{tabular}




\begin{tabular}{|c|c|c|}
\hline Individual & Availability of competent, & 'I have trained about ten guys but, \\
\hline competence & permanent employees (case 1) & when they are skilled, they send \\
\hline \multirow[t]{6}{*}{ (employee) } & Shortage of experienced, & their papers [job applications] \\
\hline & skilled, multi-tasking personnel & elsewhere' (case 1) \\
\hline & (case 4) & 'We have to recruit, but it is \\
\hline & & terribly difficult to find employees. \\
\hline & & This is a special field; it takes time \\
\hline & & for a person to learn' (case 4) \\
\hline \multirow{8}{*}{$\begin{array}{l}\text { Financial } \\
\text { competence }\end{array}$} & No observations about cost & 'It [servitisation] may be a goal in \\
\hline & effects (case 6) & the future, but it demands \\
\hline & Understanding of variable costs & resources from the company and \\
\hline & but not of the influence of fixed & the organisation. We do not \\
\hline & expenses (case 7) & possess such resources at the \\
\hline & & moment' (case 6) \\
\hline & & 'Goodness! Insurance is the \\
\hline & & greatest nuisance!' (case 7) \\
\hline \multirow{9}{*}{ management } & An entrepreneur understands the & 'It is kind of difficult to \\
\hline & risk of one supplier shutting & experiment away from here, \\
\hline & down a mine but clings to past & because the work there remains \\
\hline & security (case 5) & undone and the work here remains \\
\hline & Field-specific unwillingness of & undone' (case 5) \\
\hline & customers to develop new & 'The culture [in mining] is such \\
\hline & solutions (case 2 ) & that people want to do things that \\
\hline & Do-it-yourself attitude prevents & they have done before in the same \\
\hline & new sales (case 1 ) & way’ (case 2) \\
\hline
\end{tabular}


'You [the customer] can get the

best profit from using new skills'

(case 1)

Table 4: The current state of servitisation in the studied micros

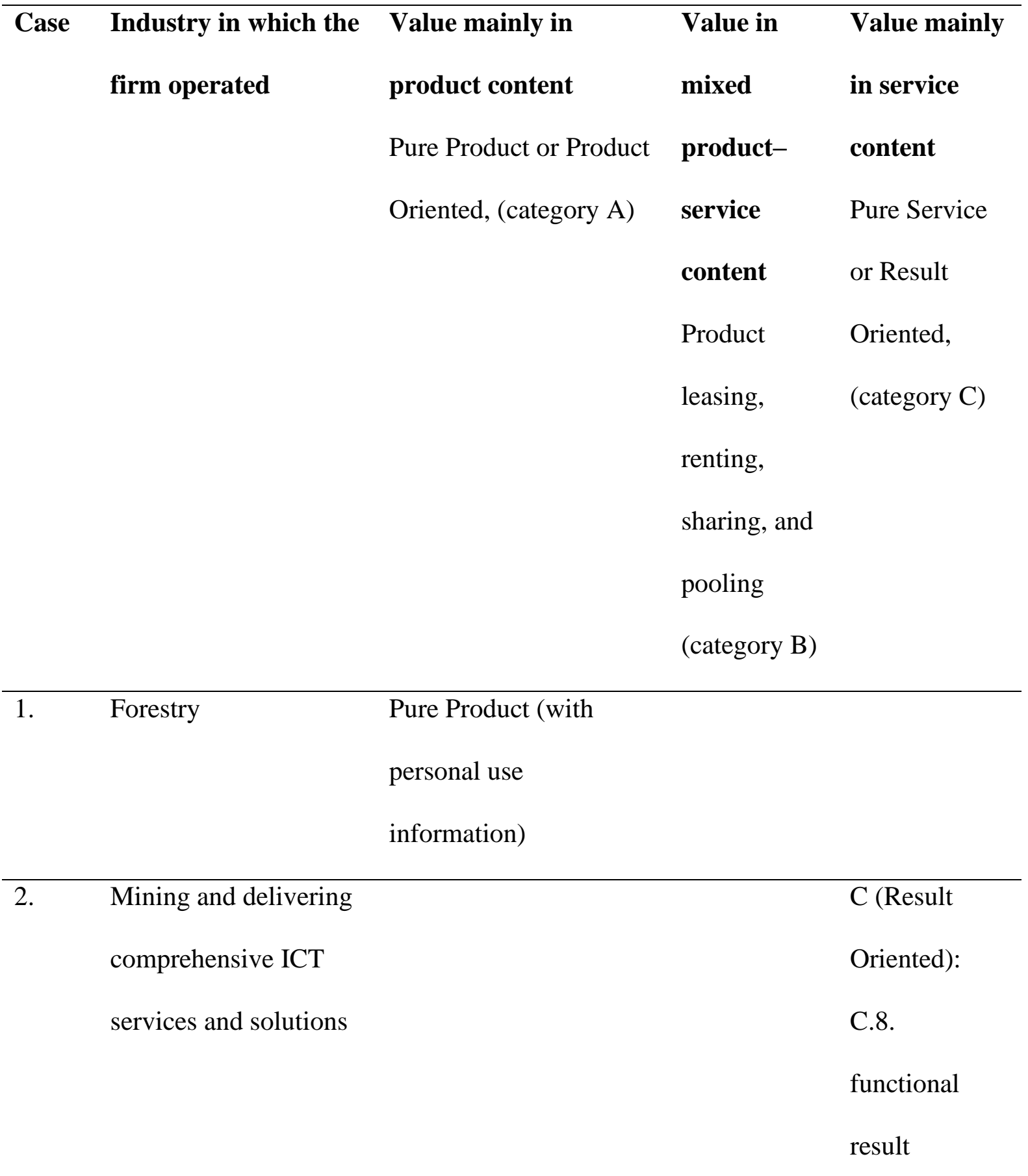




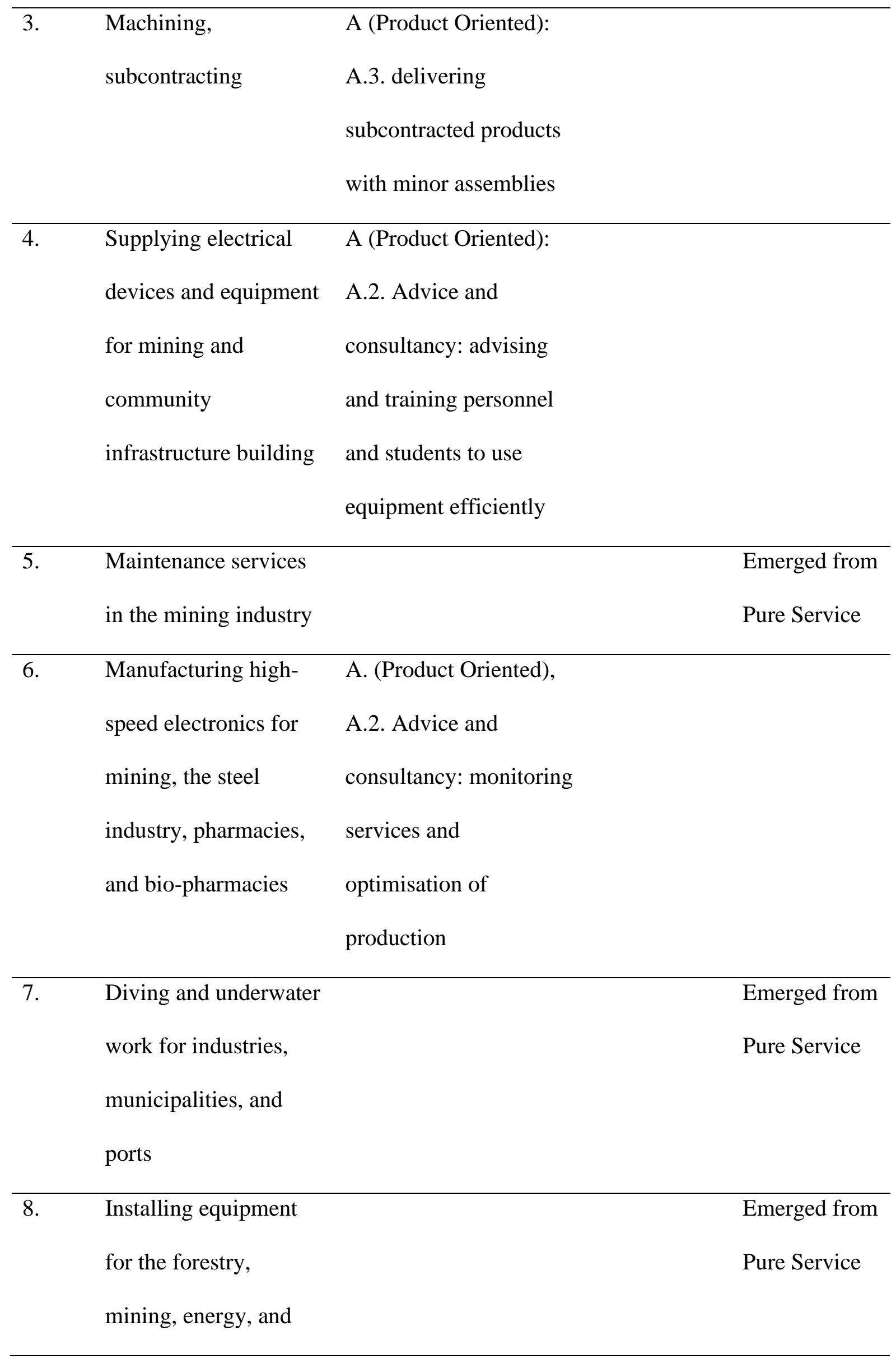




\begin{tabular}{|c|c|c|c|}
\hline & $\begin{array}{l}\text { steel industries, } \\
\text { including maintenance } \\
\text { and welding }\end{array}$ & & \\
\hline 9. & $\begin{array}{l}\text { Installation, } \\
\text { supervision, and } \\
\text { project management } \\
\text { services for } \\
\text { supervision of work, } \\
\text { planning of } \\
\text { installations, and } \\
\text { calculating contracts }\end{array}$ & & $\begin{array}{l}\text { C (Result } \\
\text { Oriented): C.8 } \\
\text { functional } \\
\text { result }\end{array}$ \\
\hline 10. & $\begin{array}{l}\text { Agricultural devices } \\
\text { and subcontracting }\end{array}$ & $\begin{array}{l}\text { Pure Product (with } \\
\text { personal user } \\
\text { information) }\end{array}$ & \\
\hline
\end{tabular}

Table 5: Limitations of human resources for micros entering the field of servitisation

\begin{tabular}{ll}
\hline Limitation & Quotations \\
\hline Lack of time & 'We do not have the time or human resources to acquire \\
& knowledge of the conditions of international business' (case \\
$1)$ & 'No time to invest in marketing and few human resources in \\
& marketing' (case 3) \\
\hline Challenges in increasing & 'We do not have any resources for servitisation yet' (case 6) \\
\hline
\end{tabular}


small firm, so small firms remain small' (case 8).

'As a key challenge and a burden, I experienced

bankruptcies. Those (bankruptcies) did not necessarily

hamper the company's directors, but did hamper some

people at a site' (case 9)

'If we sold ourselves, we would sell twice as much as our

lazy retailer does' (case 10).

Employees' individual

attitudes and conditions

Difficulties in recruiting

skilled and motivated

personnel
'We have difficulties getting personnel to work in long-

distance jobs' (case 5)

'It is a challenge to recruit personnel to work in long-

distance jobs' (case 8)

'You cannot operate in servitisation on a large scale because

of the unavailability of competent personnel' (case 1)

'Challenges in recruiting competent staff. Young people are

not interested in the field [mining]' (case 5) 


\section{FIGURES}

\section{Product-service system}

\begin{tabular}{|c|c|c|c|c|}
\hline $\begin{array}{l}\text { Value mainly } \\
\text { in product } \\
\text { content } \\
\text { Pure } \\
\text { Product }\end{array}$ & $\begin{array}{l}\text { A: Product } \\
\text { oriented } \\
\text { A 1. Product } \\
\text { related } \\
\text { A 2. Advice } \\
\text { and } \\
\text { consultancy }\end{array}$ & $\begin{array}{l}\text { B: Use } \\
\text { oriented } \\
\text { B 3. Product } \\
\text { lease } \\
\text { B 4. Product } \\
\text { renting/sharing } \\
\text { B 5. Product } \\
\text { pooling }\end{array}$ & $\begin{array}{l}\text { C: Result } \\
\text { oriented } \\
\text { C 6. Activity } \\
\text { management } \\
\text { C 7. Pay per } \\
\text { service unit } \\
\text { C 8: Functional } \\
\text { result }\end{array}$ & $\begin{array}{l}\text { Value mainly } \\
\text { in service } \\
\text { content } \\
\text { Pure Service }\end{array}$ \\
\hline
\end{tabular}

Figure 1. Product-service system (modified by Tukker, 2004)

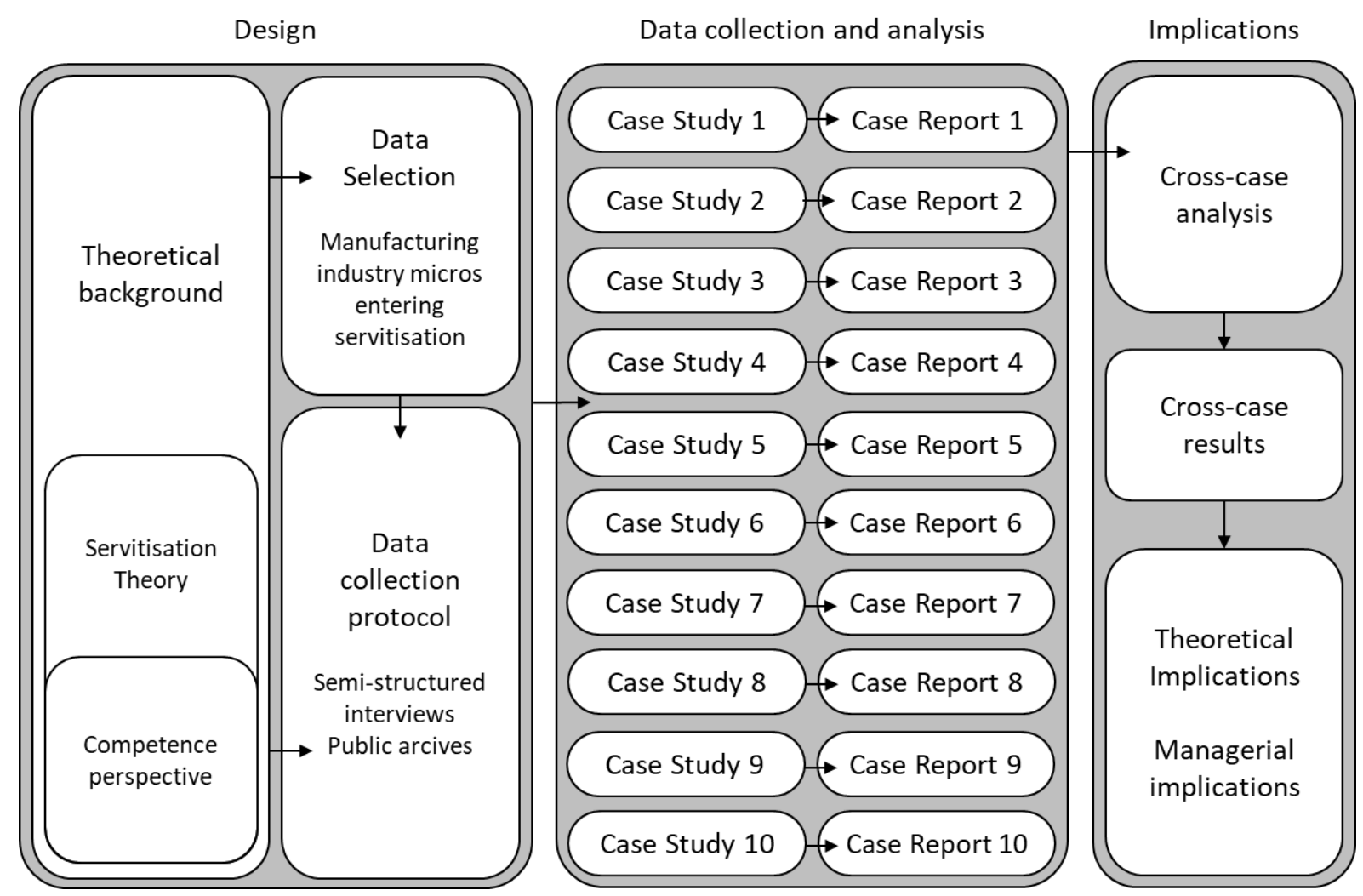

Figure 2. The research process of this study 